\title{
ЕКВІВАЛЕНТНІ СХЕМИ АКУМУЛЯТОРІВ ЕЛЕКТРОЕНЕРГІЇ, ЯКІ ПІДКЛЮЧЕНІ ДО СОНЯЧНИХ ФОТОЕЛЕМЕНТІВ
}

\begin{abstract}
Д.В. Бондаренко, канд. техн. наук
Інститут відновлюваної енергетики НАН України вул. Гната Хоткевича 20а, м. Київ, 02094, Україна

Метою роботи є побудова еквівалентної електричної схеми акумулятора, підключеного до фотоелемента та навантаження. В роботі визначено необхідність створення електричних моделей та еквівалентних схем акумуляторів електричноі енергії, а саме при підключенні до сонячних фотоелементів, в якості джерела електричної енергії. Запропоновано різні еквівалентні схеми акумуляторів електричної енергії для різного моделювання. Показано еволюиію еквівалентних схем від спрощеної до узагальненої. Описані їх параметри та викладені рівняння для струмів та напруг. Зокрема, показано спрощену еквівалентну схему акумулятора на основі Rint-моделі. Зазначено, щяо розвитком даної моделі є RC-модель, так як існують пасивні паразитні елементи. Показано, щуо є доцільним об'єднання двох моделей в одну, в Тһеvепіп-модель. Викладено, щзо подальшим розвитком моделей електрохімічного акумулятора є модел Ренделса. Ця еквівалентна схема містить додатково імпеданс Варбурга. Показано, щзо для спрощення иієё еквівалентної схеми імпеданс замінюється набором резисторноконденсаторних пар. В якості схеми заміщення фотоелемента для спрощення використано ідеальне джерело напруги та резистор з конденсатором. Для більш широкого моделювання роботи фотоелемента, в якості схеми замімення було використано ідеальне джерело струму та нелінійні пасивні елементи. Таким чином було отримано узагальнену еквівалентну електричну схему акумулятора, підключеного до фотоелемента та навантаження. Побудовані рівняння для струмів та напруг в отриманій схемі заміщення. Бібл. 6, рис. 6.
\end{abstract}

Ключові слова: еквівалентні схеми, електрична модель, акумулятор, сонячний фотоелемент, моделювання.

\section{EQUIVALENT CIRCUITS OF ELECTRIC POWER ACCUMULATORS CONNECTED TO SOLAR PHOTOCELLS}

\section{Bondarenko, candidate of technical science}

Institute of Renewable Energy, National Ukrainian Academy of Science 02094, 20A Hnata Khotkevycha Str., Kyiv, Ukraine

The goal of work is to create an equivalent electric circuit of the battery connected to the photocell and load. The work defined the necessity of creating electric models and equivalent circuits of electric energy accumulators, as well as when connected to solar photovoltaic cells. Different equivalent schemes of electric energy batteries are shown for different simulations. The evolution of equivalent circuits from simplified to generalized is shown. Described their parameters and set levels of current and voltage. It is shown that the simplified equivalent circuit of the battery based on Rint-models. It is determined that the developed model is an LCD model, since there are passive parasitic elements. It is shown that the subsidiary associations of two models in one, in the Theveninmodel. It is stated that the further development of models of an electrochemical battery has the model of Randels. This equivalent circuit contains an additional Warburg impedance. It is shown that to simplify this equivalent circuit, the impedance is replaced by a set of resistor-capacitor pairs. In the following, the connection of the general equivalent scheme of replacement of the battery to the photocell and load is shown. Its parameters are painted. As the photocell's replacement schemes, for simplicity, ideal voltage sources and capacitor resistors are used. Subsequently, for the wider modeling of the photocell, as ideal circuit current and non-linear passive elements, replacement of the circuit was used. Thus a generalized equivalent electrical circuit diagram of the battery connected to the photocell and load was obtained. Made of the equations for currents and voltage of the equivalent circuit. Ref. 6 , fig. 6 .

Keywords: equivalent circuits, electric model, accumulator, solar PV-element, simulation.

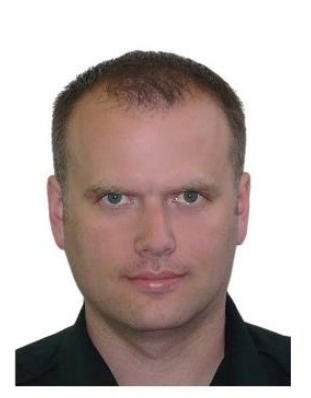

Д.В. Бондаренко D. Bondarenko
Відомості про автора:

Старш. наук. співробітник Інституту відновлюваної енергетики НАН України,

Відділ сонячної енергетики.

Освіта: Київський національний університет ім.Т.Шевченка (Радіофізичний факультет). Аспірантура Інституту електродинаміки НАН України

Наукова сфера: к.т.н. (теоретична електротехніка), квантова електроніка, фото- та оптоелектроніка, відновлювана енергетика

Публікації: 43.

ORCID: 0000-0002-5629-930X

Контакти: тел: +380509729992

e-mail: dima7007bond@gmail.com
Author information:

Senior scientist of Institute of Renewable Energy, National Ukrainian Academy of Science. Solar energy department

Education: Kyiv national university T.Shevchenko (Radiophysics department). Postgraduate school of Institute of electrodynamics of NAS Ukraine Reasearch area:

$\mathrm{PhD}$ (theoretical electrotechnic), quantum electronic, photo- and optoelectronic, renewable energy

Publications: 43

ORCID: 0000-0002-5629-930X

Contacts: tel: +380509729992

e-mail:dima7007bond@gmail.com

(C) Д.В. Бондаренко, 2019 
Вступ. Стрімке поширенні сонячних фотоелементів, як джерел електричного живлення, потребує застосування акумуляторів електричної енергії. Це необхідно, так як фотогенерація не $\epsilon$ постійною і передбачуваною. Тобто, застосування електричних акумуляторів разом 3 генеруючими фотоелементами дає нам певну стабільність електроживлення.

Дослідження та моделювання систем фотоелемент-акумулятор дозволить розробляти сучасні ефективні електричні та електронні системи. Треба відзазначити, що моделювання електричних систем за допомогою електричних моделей (еквівалентних схем) $є$ ефективним інструментом аналізу та проектування систем, в тому числі 3 використанням відновлюваних джерел енергії, зокрема сонячних фотоелементів, батарей та акумуляторів.

Завзначимо, що різне застосування електрохімічних акумуляторів та різні режими роботи потребують різних еквівалентних схем. В загальному випадку в еквівалентних схемах акумуляторів використовується кероване джерело напруги 3 ємнісними та вольт-амперними характеристиками, які описують режим роботи конкретних типів акумуляторів, в тому числі і літій-іонного. Треба зазначити, що для спрощеного представлення, наприклад, при використанні акумулятора, в якості короткочасної підтримки джерела живлення та згладжування пульсацій, можливо використати звичайну ємність, підключену паралельно до джерела, в якості схеми заміщення.

Аналіз моделей еквівалентних схем. Для розширеного моделювання використовують еквівалентні схеми 3 пасивними, паразитними елементами, які спотворюють ідеальні статичні та динамічні характеристики акумулятора, як джерела вторинного живлення. Найбільш простою є так звана "Rint-модель" (рис.1), яка містить опір, який послідовно підключений до ідеального джерела напруги [1].

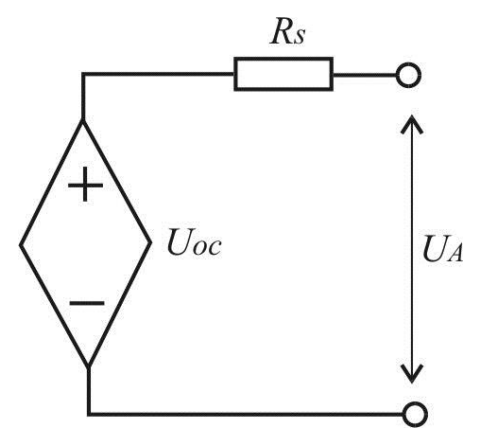

Рис. 1. Rint-модель.
Для якої використовується рівняння:

$$
U_{A}=U_{O C}-I_{A} \cdot R_{S} .
$$

Модель "Rint", як показано на рис.1 і в рівнянні (1), реалізує ідеальний джерело напруги $U_{o c}$, яке визначає напругу в розімкнутому акумуляторі (напругу холостого ходу) і послідовний опір. Обидва параметри, опір $R_{S}$ і напруга холостого ходу $U_{O C} \epsilon$ функціями рівня зарядженості акумулятора $(\mathrm{SoC})$, рівня зносу $(\mathrm{SoH})$ і температури. В даній схемі струм навантаження $I_{A}$ має позитивне значення при розряді і від'ємне значенням при зарядці. $U_{A} \in$ напругою на зовнішніх клемах акумуляторної батареї і $U_{A}>U_{O C}$ коли акумулятор заряджається, $U_{A}<U_{O C}$ коли акумулятор розряджається. Також зазначимо, що опір $R_{S}$, на якому виділяється тепло, визначає ККД акумулятора.

Моделі "Rint" достатньо для простих конструкцій в електроніки, але недостатньо для складної побутової електроніки та електричного моделювання миттєвої реакції на зміну вхідного та вихідного струмів. На практиці в акумуляторах спостерігається динамічне запізнення відповіді на зміну параметрів, які наприклад, викликані повільними процесами дифузії в елементах акумуляторної батареї.

Таким чином, розвитком схеми заміщення $\epsilon$ R-C-модель. В цій еквівалентній схемі до основної ємності, яка моделює накопичення заряду в акумуляторі, додаються ємність та три опори, які підключені послідовно та паралельно і моделюють внутрішні процеси та конструктивні елементи акумулятора [1]. Але доцільним буде об'єднання вищеописаних моделей в одну, в так звану Thevenin-модель.

В цій моделі використовуються керовані джерела (рис. 2) напруги та R-C-ланцюг для повного представлення процесів накопичення заряду та відображення внутрішніх та зовнішніх процесів в акумуляторі. Відповідні рівняння мають вигляд:

$$
\begin{array}{r}
U_{A}=U_{O C}-U_{R C 1}-I_{A} \cdot R_{S}, \\
I_{A}=C_{1} \frac{d U_{R C 1}}{d t}+\frac{U_{R C 1}}{R_{1}},
\end{array}
$$

де $U_{R C l}-$ напруга на паралельному R-Cланцюгу.

Fig. 1. Rint-model. 


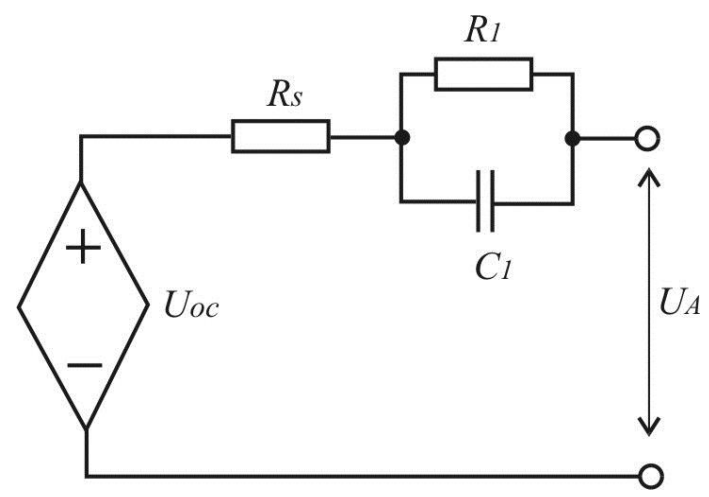

Рис. 2. Thevenin-модель.

Fig. 2. Thevenin-model.

Альтернативною є модель, яка має назву Еквівалентна схема Рендлса (рис.3), що враховує електрохімічні процеси в акумуляторі і моделює електрохімічних реакцій та дифузію електроактивних частинок до плоских електродів. Ця модель має такий же R-C-ланцюг, як і попередня, але додатково містить елемент, який називається імпеданс Варбурга [2].

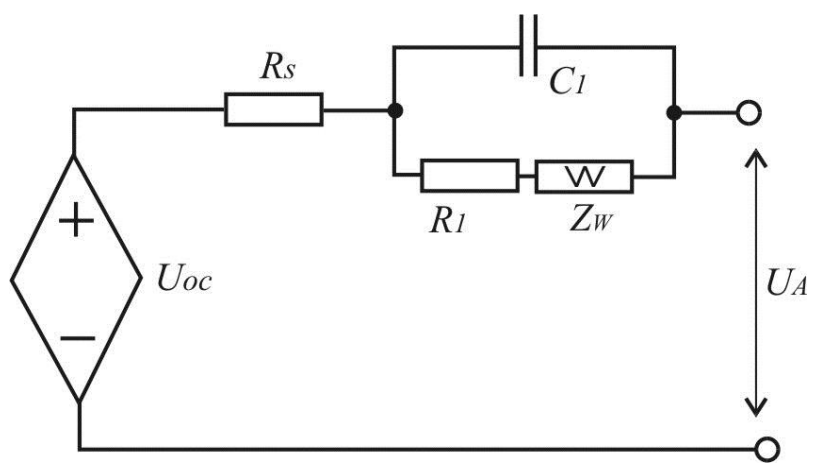

Рис. 3. Еквівалентна схема Рендлса.

Fig. 3. Equivalent circuit of Randles.

В моделі Рендлса $R_{S}$ моделює активний опір електроліту, $R_{l}$ - активний опір, пов'язаний з переносом заряду та моделює падіння напруги на переході електроліт-електрод; $C_{1} \in$ двошаровою ємністю та моделює процес накопичення заряду в електроліті і на поверхні електроду; $Z_{W}-$ імпеданс Варбурга, який моделює повільні процеси дифузії.

Еквівалентна схема Рендлса $є$ однією 3 найпростіших моделей, що описують електрохімічні процеси. В реальних електрохімічних системах спектри імпедансу зазвичай більш складні i, таким чином, схема Рендлса може не давати відповідних результатів. Тому була запропонована модель, в якій цей імпеданс замінюється ланцюгом паралельно з'єднаних опору та ємності. Для точної еквівалентності потрібно нескінченне число таких резисторно-конденсаторних пар; але схема часто може бути змодельована 3 використанням малого числа пар R-C, навіть двома (рис.4).

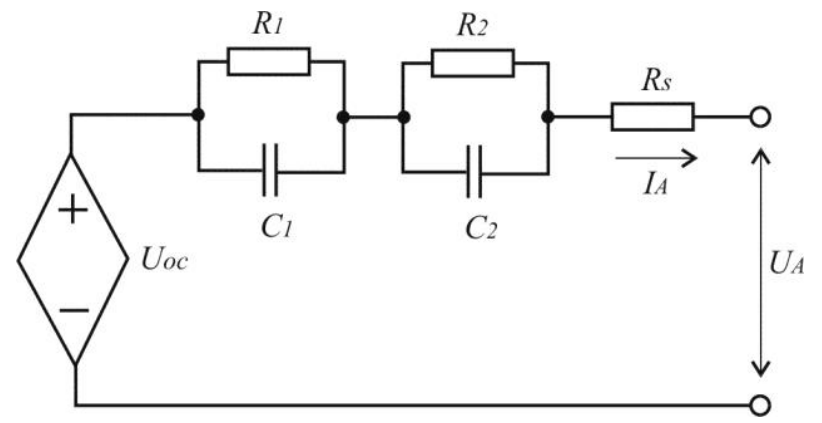

Рис. 4. Еквівалентна схема з R-C-парами.

Fig. 4. Equivalent circuit with R-C-pairs.

В цій еквівалентній схемі кероване джерело струму $U_{O C}$ відповідає напрузі на акумуляторі без навантаження, тобто холостого ходу, опір $R_{S}$ це внутрішній омічний опір акумулятора. Паразитні елементи $R_{1}$ та $R_{2}$ моделюють електрохімічні процеси в середині акумулятора, а ємності $C_{l}$ та $C_{2} \in$ ефектиними ємностями які відповідають за перенос енергії в акумуляторі по анології з моделю Рендлса. Рівняння кола для такої моделі мають наступній вигляд:

$$
\begin{gathered}
U_{A}=U_{O C}-U_{R C 1}-U_{R C 2}-I_{A} \cdot R_{S}, \\
I_{A}=C_{2} \frac{d U_{R C 2}}{d t}+\frac{U_{R C 2}}{R_{2}}, \\
C_{1} \frac{d U_{R C 1}}{d t}+\frac{U_{R C 1}}{R_{1}}=C_{2} \frac{d U_{R C 2}}{d t}+\frac{U_{R C 2}}{R_{2}},
\end{gathered}
$$

де $U_{R C l}$ та $U_{R C 2}$ - це напруги на R-C-ланцюгах.

Таким чином, маючи загальну еквівалентну схему акумулятора, можно проводити моделювання та оптимізацію електричних кіл 3 джерелами живлення, акумуляторами та споживачами.

Розглянувши еквівалентну схему фотоелемента [3] можно створити модель системи фотоелемент-акумулятор-навантаження (рис. 5). В цій схемі, крім вищеописаних параметрів, додаються кероване джерело напруги $U_{P V}$, яке моделює генерацію струму в фотоелементі і залежить від рівня інсоляції, а також температури та конструктивних параметрів фотоелемента. Опір $R_{P V} \mathrm{\epsilon}$ внутрішнім опором фотоелемента, а ємність $C_{P V} \epsilon$ паразитною і залежить властивостей від напівпровідника та конструкції фотоелементу. Опір $R_{L} \epsilon$ опором навантаження, а напруга $U_{A} \in$ напругою на навантаженні. 


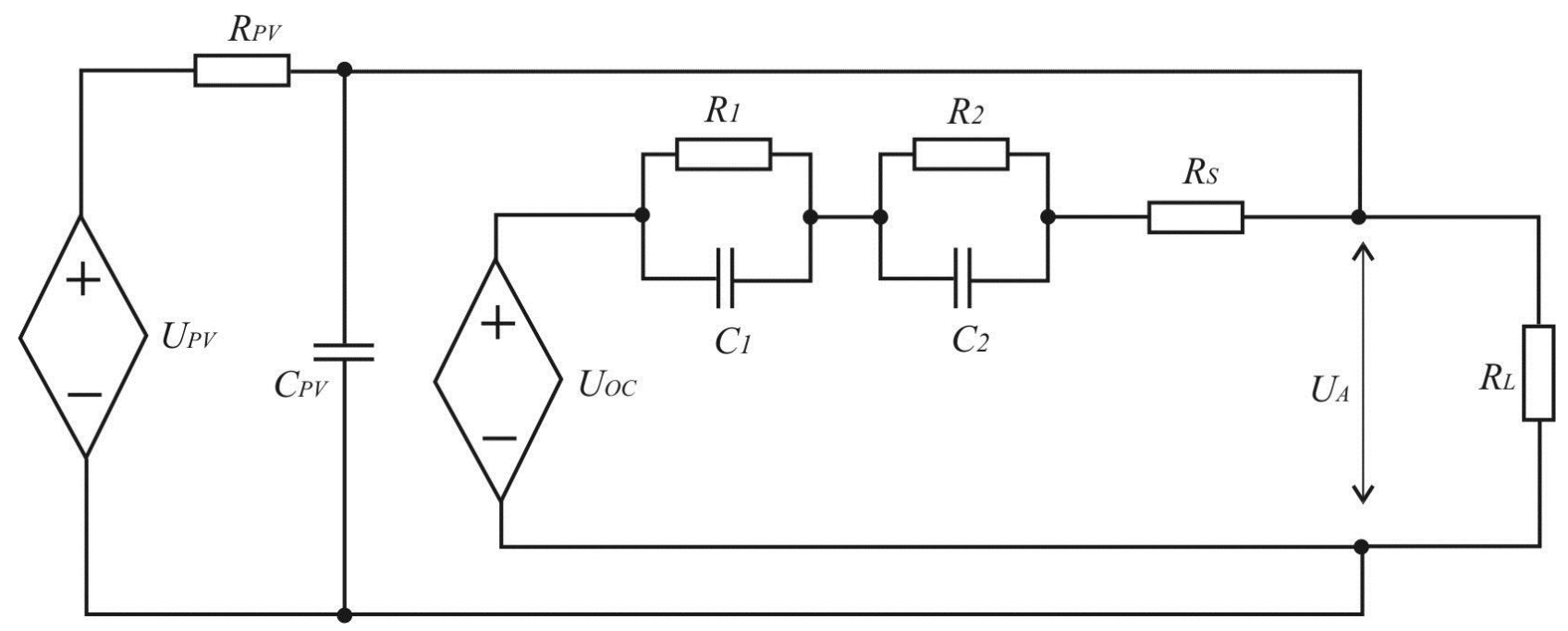

Рис. 5. Модель системи фотоелемент-акумулятор-навантаження.

Fig. 5. Model of system PVelement-accumulator-load.

Як альтернатива, яка поглиблює аналіз процесів в сонячних фотоелементах, можливо використати трохи іншу еквівалентну схему, ніж на рис. 5. Для цього введемо в схему заміщення фотоелемента нелінійний опір та нелінійну ємність (рис. 6). Нелінійна ємність $C_{P V}$ виникає завдяки дифузійній та бар'єрній ємностям в напівпровіднику фотоелемента і впливає на перехідні процеси. А опір $R_{P V} \in$ внутрішнім опором джерела живлення і визначає його вольт-амперну характеристику. Опір $R_{C}$ і індуктивність $L_{W} \in$ опором і індуктивністю контактних з'єднань відповідно [5].

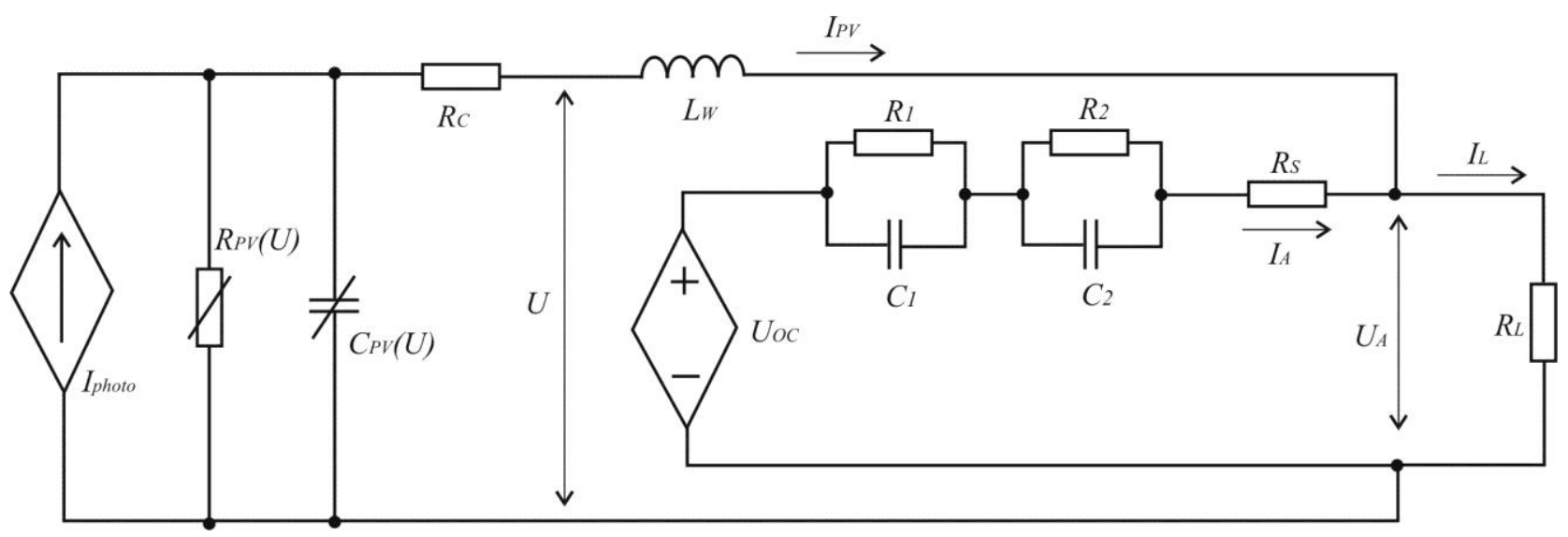

Рис. 6. Еквівалентна схема 3 нелінійними елементами.

Fig. 6. Equivalent circuit with nonlinear elements.

Висновок. Розглянувши отриману схему, можна зробити висновок про перспективність застосування загальної еквівалентної схеми системи для моделювання пристроїв, в якій навантаження живиться від фотоелемента та акумулятора, наприклад автономних систем моніторингу, телеметрії або керування [5]. Така схема дозволяє в одному обчислювальному процесі провести моделювання і аналіз таких систем, використовуючи загальновживані пакети програмного моделювання, або розробляти власні програмні продукти на сучасних мовах програмування [6].
1. Hongwen He, Rui Xiong, Jinxin Fan. Evaluation of Lithium-Ion Battery Equivalent Circuit Models for State of Charge Estimation by an Experimental Approach. Energies. 2011. № 4. C. 582-598.

2. Randles circuit. [Electronic resource]. URL: https://en.wikipedia.org/wiki/Randles_circuit.

3. Bondarenko D.V. Use of electrical equivalent circuits at simulation optoelectronic systems. 5th International Workshop on Laser and Fiber-Optical Networks Modeling. 2003. Proceedings of LFNM 2003. Pp.72-74.

4. Бондаренко Д.В. Використання еквівалентних електричних схем для розрахунку перехідних процесів у колах 3 фотобатареєю та нелінійним оптоелектронним навантаження. Праці Інституту електродинаміки НАН України. Збірник 
наукових праць. № 2(2). К. 2002. С.13-15.

5. Бондаренко Д.В. Використання сонячних батарей для побудови автономних систем екологічного моніторингу. Відновлювана енергетика. № 3(42). 2015. С.18-20.

6. Бондаренко Д.В., Щокіна В.А., Пономаренко О.П. Використання мови програмування Java для моделювання в сонячній енергетиці. Матеріали XIX міжнародної науковопрактичної конференції "Відновлювана енергетика та енергоефективності XXI століття". Київ. 2018. С. 255-259.

\section{REFERENCES}

1. Hongwen He, Rui Xiong, Jinxin Fan. Evaluation of Lithium-Ion Battery Equivalent Circuit Models for State of Charge Estimation by an Experimental Approach. Energies. 2011. № 4. C. 582-598. [in English].

2. Randles circuit. [Electronic resource]. URL: https://en.wikipedia.org/wiki/Randles circuit. [in English].

3. Bondarenko D.V. Use of electrical equivalent circuits at simulation optoelectronic systems. 5th International Workshop on Laser and Fiber-Optical Networks Modeling. 2003. Proceedings of LFNM 2003. Pp.72-74. [in English].

4. Bondarenko D.V. Vykorystannya ekvivalentnykh elektrychnykh skhem dlya rozrakhunku perekhidnykh protsesiv u kolakh $\mathrm{z}$ fotobatareyeyu ta neliniynym optoelektronnym navantazhennya. [Useing of equivalent electrical circuits for calculating transition processes in circles with pv-battery and nonlinear optoelectronic load]. Proceedings of the Institute of Electrodynamics of the National Academy of Sciences of Ukraine. Collection of scientific works. No. 2(2). K. 2002. Pp. 13-15. [in Ukrainian].

5. Bondarenko D.V. Vykorystannya sonyachnykh batarey dlya pobudovy avtonomnykh system ekolohichnoho monitorynhu. [Useing of solar panels for the design of autonomous systems of environmental monitoring]. Vidnovluvana energetika. № 3(42). 2015. Pp.18-20. [in Ukrainian].

6. Bondarenko D.V., Shchokina V.A., Ponomarenko O.P. Vykorystannya movy prohramuvannya Java dlya modelyuvannya $\mathrm{v}$ sonyachniy enerhetytsi. [Using the Java programming language for modeling in solar power]. Materials of the 19th International Scientific and Practical Conference "Renewable Energy and Energy Efficiency of the 21st Century". Kyiv. 2018. Pp. 255-259. [in Ukrainian].

\section{ЭКВИВАЛЕНТНАЯ СХЕМА АККУМУЛЯТОРОВ ЭЛЕКТРОЭНЕРГИИ, КОТОРЫЕ ПОДКЛЮЧЕНЫ К СОЛНЕЧНЫМ ФОТОЭЛЕМЕНТАМ}

\section{Д.В. Бондаренко, канд. техн. наук}

Институт возобновляемой энергетики НАН Украины ул. Гната Хоткевича 20а, г. Киев, 02094, Украина

Целью работы является построение эквивалентной электрической схемы аккумулятора, подключенного к фотоэлементу и нагрузке. В работе определена необходимость создания электрических моделей и эквивалентных схем аккумуляторов электрической энергии, а именно при подключении к солнечным фотоэлементам, в качестве источника электрической энергии. Показаны различные эквивалентные схемы аккумуляторов электрической энергии, для разного моделирования. Показана эволючия эквивалентных схем от упрощенной $к$ обобщенной. Описанные их параметры $и$ изложенны уравнения для токов и напряжений. В частности, показано упрощенную эквивалентную схему аккумулятора на основе Rint-модели. Отмечено, что развитием данной модели является $R C$-модель, так как существуют пассивные паразитные элементы. Показано, что иелесообразно объединение двух моделей в одну, в Thevenin-модель. Изложено, что дальнейшим развитием моделей электрохимического аккумулятора является модель Ренделса. Эта эквивалентная схема содержит дополнительно импеданс Варбурга. Показано, что для упрощения этой эквивалентной схемы, сопротивление заменяется набором резисторноконденсаторных пар. В дальнейшем, показано подключение общей эквивалентной схемы замещения аккумулятора фотоэлементу и к нагрузке. Расписаны ее параметры. В качестве схемы замещения фотоэлемента, для упрощения, использован идеальный источник напряжения и резистор $c$ конденсатором. В дальнейшем, для более широкого моделирования работы фотоэлемента, в качестве схемы замещения были использованы идеальный источник тока и нелинейные пассивные элементы. Таким образом, было получено обобщенную эквивалентную электрическую схему аккумулятора, подключенного к фотоэлементу и нагрузке. Построены уравнения для токов и напряжений в полученной схеме замещения. Сделаны выводы. Библ. 6, рис. 6.

Ключевые слова: эквивалентные схемы, электрическая модель, аккумулятор, солнечный фотоэлемент, моделирование. 